\title{
CysLT1 receptor antagonist alleviates pathogenesis of collagen- induced arthritis mouse model
}

\author{
Minwen $\mathrm{Xu}^{1}$, Ruiyun Hong ${ }^{1}$, Xiaoli Zhang ${ }^{2}$, Hailin Zou' ${ }^{2}$, Yi Zhang ${ }^{2}$, Zhiping Hou ${ }^{2}$ \\ and Liefeng Wang ${ }^{2}$ \\ ${ }^{1}$ First Affiliated Hospital, Gannan Medical University, Ganzhou, China \\ 2 Department of Biotechnology, Gannan Medical University, Ganzhou, China \\ Correspondence to: Liefeng Wang, email: 469730795@qq.com \\ Keywords: collagen-induced arthritis; cysteinyl leukotrienes; CysLT1 antagonist; montelukast; IL-17A; Immunology and Microbiology \\ Section; Immune response; Immunity \\ Received: April 12, $2017 \quad$ Accepted: November 07, $2017 \quad$ Published: November 26, 2017
}

Copyright: Xu et al. This is an open-access article distributed under the terms of the Creative Commons Attribution License 3.0 (CC BY 3.0), which permits unrestricted use, distribution, and reproduction in any medium, provided the original author and source are credited.

\section{ABSTRACT}

Cysteinyl leukotrienes (CysLTs) play a key role in inflammatory diseases such as asthma and their receptors' antagonists are currently used as anti-asthmatic drugs. CysLTs have also been found to participate in other inflammatory reactions. Here, we reported that in rheumatoid arthritis (RA) animals model, collagen-induced arthritis, (CIA), CysLT1, a receptor for CysLTs, was up-regulated in hind paw and lymph node, while CysLTs levels in the blood were also higher than normal mice. Montelukast, a drug targeting CysLT1, has been shown to effectively reduce the CIA incidence, peak severity, and cumulative disease scores. Further study indicated that CysLT1 signaling did not affect the differentiation of pathogenic $T$ helper cells. We conclude that montelukast may play important roles in the pathogenesis of CIA, mainly by inducing infiltration of pathogenic $T$ cells, increasing IL-17A secretion and expression of IL-17A, while these effects can be blocked by CysLT1 antagonists. Our findings indicate that antagonist of CysLT1 receptor may be used to treat rheumatoid arthritis.

\section{INTRODUCTION}

Rheumatoid arthritis (RA) is a chronic inflammatory disease characterized by immune-mediated synovitis, local inflammatory cells infiltration and neoangiogenesis $[1,2]$. Although the etiology of the disease remains unclear, it is considered a complex chronic disorder which inflammatory mediators played a crucial role in the rheumatoid synovium and synovial fluid [3]. IL-17A, an important proinflammatory cytokine, has been reported to participate in RA pathogenesis [4]. IL-17 receptors are positive in progenitor cells from RA cartilage, IL-17A/F increase the RUNX2 and IL-6 protein expression levels and up-regulate the MMP3 mRNA expression levels. Anti IL-17 antibody reduced the secretion of IL-6 protein level and increased the secretion of IL-10 protein level [5]. Knocking out IL-17A or treatment with anti IL17 antibodies or blocking IL-17 receptor may alleviate arthritis [6-8]. Of course more clinical trials are need to confirm those effect since occasionally contradictory results with IL-17 were found in certain RA models [9].

$\mathrm{G}$ protein-coupled receptors (GPCRs) mediate many important biological pathways and are targeted by the largest proportion in the current medicine market $[10,11]$. Many GPCRs have been shown to link to the pathogenesis of RA [12-14].

Leukotrienes (LTs), an endogenous signaling molecule, are potent pro-inflammatory mediators which involve in host defense and some inflammatory diseases [15-18] via designated GPCRs. Arachidonic acid is sequential catalyzed by cytosolic phospholipase A2 $\alpha$ (cPLA2 $\alpha$ ), 5-lipoxygenase (5-LO) and LTC4 synthase (LTC4S). LTC4, LTD4 and LTE4 are released successively which are called CysLTs $[19,20]$. The physiological functions of CysLTs are mediated via two CysLTs receptors, CysLT1 and CysLT2 [21, 22]. Inhibitors of 5-LO and antagonists of CysLT1 are used in treatment of asthma [23, 24].

The role of CysLT1 signaling pathway in the pathogenesis of RA is unclear. In our study, we discovered in CIA mouse, a RA animal model, $c P L A 2 \alpha$, 5-LO and CysLT1 mRNA levels were up-regulated, and CysLTs levels in serum were also elevated. Blocking of CysLT1 with its antagonist, montelukast, relieved the 
CIA's clinical symptoms. We demonstrated that CysLTs signaling pathway play a vital role in the pathogenesis of CIA, primarily by up-regulating the expression of $I L-17 \mathrm{~A}$ gene, then inducing production of IL-17A, and infiltration of pathogenic $\mathrm{T}$ cells which can be relieved by blocked CysLT1 signaling pathway. Our results demonstrate that the CysLT1 antagonists may be used to treat RA.

\section{RESULTS}

\section{Key ingredients of CysLT1 signaling pathways were up-regulated in the pathogenesis of CIA}

CIA was induced in DBA male mice by immunization with Chicken type II collagen [25]. To describe the role CysLTs played in the pathogenesis of CIA, we firstly detected the mRNA levels of key ingredients in CysLT1 signaling pathways, including the receptor CysLT1 and three CysLTs synthesizing enzymes (cPLA2 $\alpha, 5-\mathrm{LO}$ and LTC4S) in hind paw and lymph node at week $0,3,6,9,12,15$ post booster immunization (Figure 1 and Supplementary Figure 1). In hind paw, the $c P L A 2 \alpha$ mRNA was increased at week 3 and week 6 post booster immunization (Supplementary Figure 1A), the 5-LO mRNA level was observably increased from week 3 post booster immunization till reached its plateau at week 6 (Figure 1A). In lymph node, the $c P L A 2 \alpha$ mRNA was increased at week 3 and week 6 post booster immunization (Supplementary Figure 1B), the level of 5-LO mRNA increased from week 6 and maintained a relatively stable level after week 9 (Figure 1B). In contrast, $L T C 4 S$ were not significantly altered in both hind paw and lymph node.

CysLT1 was found to be significantly up-regulated from week 3. In hind paw, CysLT1 peaked at week 9, and then slowly declined after that (Figure 1C). In lymph node, however, CysLT1 peaked at week 6 and displayed a plateaued up-regulation between week 6 and week 15 (Figure 1D). We then measured the level of total CysLTs $\left(\mathrm{LTC}_{4}, \mathrm{D}_{4}, \mathrm{E}_{4}\right)$ in CIA mice. Compare to control mice, the CysLTs levels in serum (Figure 2), in hind paw (Supplementary Figure 2A) and in lymph node (Supplementary Figure 2B) of CIA mice (6 weeks post booster immunization) were significantly increased. The up-regulation of key ingredients of CysLT1 signaling pathways indicates that CysLT1 signaling pathways may play a crucial role in CIA pathogenesis.
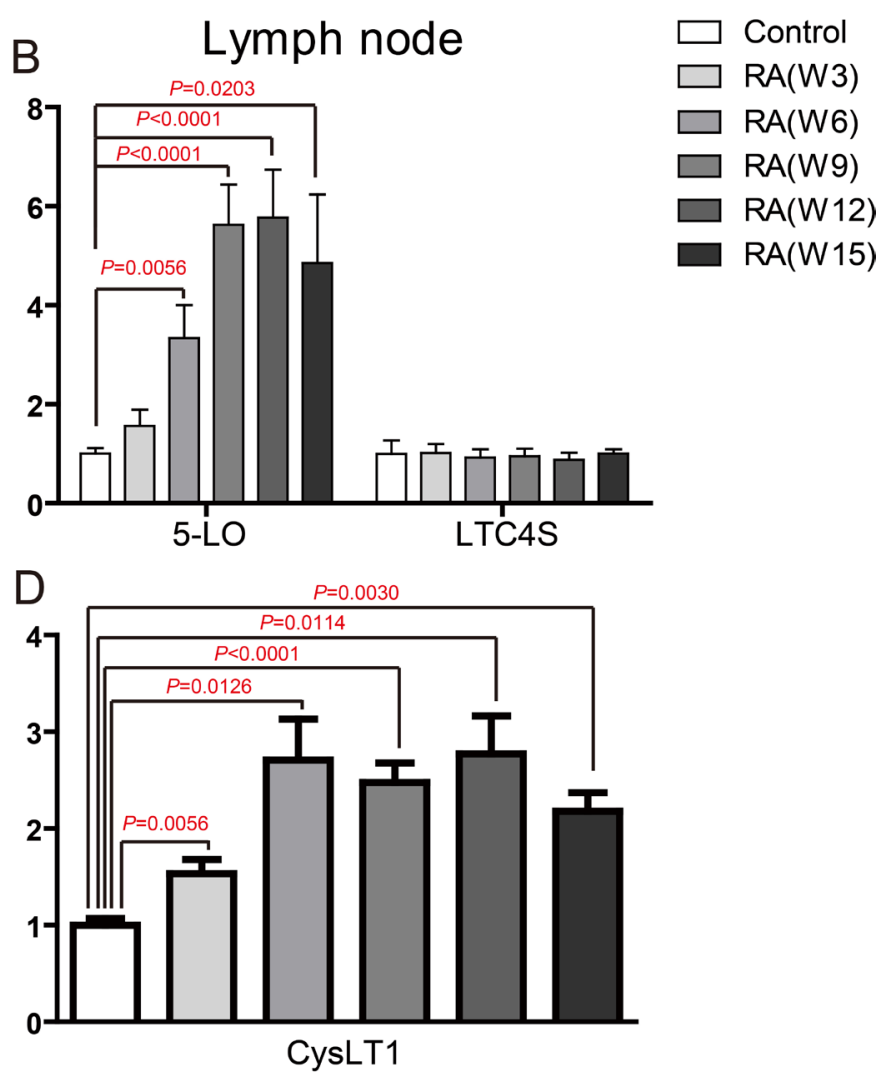

Figure 1: Up-regulation of CysLT receptors and synthesizing enzymes during CIA pathogenesis. mRNA was isolated from hind paw, lymph node of control mice and CIA mice at weeks 3, 6, 9, 12, 15 post booster immunization. qPCR was performed to analyze gene expression. Results were normalized to $\beta$-actin expression in the same sample and then normalized to the control. A.-D. 5- $L O$ and LTC4S gene expression in hind paw (A), lymph node (B), CysLT1 gene expression in hind paw (C), lymph node (D). Data are presented as mean \pm SEM $(\mathrm{n}=6)$ and are representative of three independent experiments. ${ }^{*} p<0.05, * * p<0.01$ and $* * * p<0.001$, versus control (Student's $t$-test). 
Treated with CysLT1 antagonists alleviated clinical symptoms and lesion with infiltration of pathogenic $\mathrm{T}$ cells in CIA

To ulteriorly estimate the participation of CysLT1 signaling pathways in CIA pathogenesis, montelukast, one of CysLT1 receptor antagonists, was used to treat in CIA mice. Montelukast was injected once daily via i.p. while vehicle was injected as the control from day 1 post booster immunization till the end of the experiments. The results clearly showed montelukast significantly ameliorated the severity of CIA (Figure 3).

Histopathological examination of hind paw was performed at weeks 9 post booster immunization. Compared to vehicle treatment, montelukast decreased synovial hyperplasia, inflammatory cells infiltration into synovium and bone involvement (Figure 4A). The lesion leukocytes infiltration in hind paw sections were further analyzed by immunofluorescent staining and in synovial fluid were analyzed by flow cytometry. Montelukast treatment could reduce the number of $\mathrm{CD}^{+} \mathrm{T}$ cells (Figure 4B, Supplementary Figures $3 \mathrm{~A}$ and $4 \mathrm{~A}$ ) and IL-17A $\mathrm{A}^{+} \mathrm{T}$ cells (Figure 4C, Supplementary Figures 3B and $4 \mathrm{~B}$ ) in the hind paw sections and in synovial fluid, which were consistent with H\&E staining result. We also checked the anti-collagen II auto-Abs ELISA levels in two experimental groups. The results showed that montelukast could decrease the levels of anti-collagen II auto-Abs (Supplementary Figure 5).

\section{CysLT1 signaling did not influence $T$ cell proliferation and differentiation}

We are curious to learn whether CysLT1 signaling pathway was participate in $\mathrm{T}$ cell proliferation and differentiation. In CIA animals, montelukast did not obviously decrease the percentage of total leukocytes $\left(\mathrm{CD} 45^{+}\right.$cells), $\mathrm{CD}^{+} \mathrm{T}$ cells, $\mathrm{CD} 8^{+} \mathrm{T}$ cells and $\mathrm{B}$ cells in blood (Figure 5A-5H). We found there were no differences in the frequency of Th1, Th17 or Treg cells in the CD4 population between two experimental groups, though the trends of decrease could be observed. We also checked T cell proliferation in spleen (Supplementary Figure 6A) and lymph node (popliteal and inguinal, Supplementary Figure $6 \mathrm{~B})$ and there were no differences in experimental groups. We further checked the total cells number in spleen and lymph node (Supplementary Figure 7). Cell numbers were no change in spleen (Supplementary Figure 7A) but some change in lymph node (Supplementary Figure 7B). We then checked the absolute cell numbers of B cells, $\mathrm{CD}^{+} \mathrm{T}$ cells and $\mathrm{CD} 4^{+} \mathrm{T}$ cells' subsets in lymph node. We found that $\mathrm{CD}^{+} \mathrm{T}$ cells (Supplementary Figure 7D), Th1 and Th17 cells (Supplementary Figure 7E) number were decreased, while B cells (Supplementary Figure 7C) and Treg cells (Supplementary Figure 7E) number were no change. We further labelled T cells with CFSE in lymph node and we confirmed that montelukast did not influence $\mathrm{T}$ cell proliferation (Supplementary Figure 8). Since Ki67 is the proliferation related markers, we check the $\mathrm{CD} 4^{+} \mathrm{Ki} 67^{+} \mathrm{T}$ cells and we found that montelukast did not influence the $\mathrm{CD}^{+} \mathrm{Ki} 67^{+} \mathrm{T}$ cells number in experimental groups (Supplementary Figure 9). To exclude that montelukast may induce apoptosis, we checked the apoptosis related marker (Bcl-2 and Caspase-3) and we found that montelukast did not expedite apoptosis (Supplementary Figure 10). We further exam whether CysLTs or the antagonist montelukast would affect Th1, Th17 or Treg differentiation in vitro. Naive $\mathrm{CD}^{+} \mathrm{T}$ cells were activated with anti-CD3 and anti-CD28 antibodies, and then induced to differentiate into Th1, Th17 or Treg cells by supplementation with differentiation factors and $\mathrm{LTD}_{4}(100 \mu \mathrm{m})$ or montelukast $(100 \mu \mathrm{m})$. Cells were harvested 3 days later and performed intracellular staining for IFN- $\gamma$, IL-17, or Foxp3 [22]. Upon FACS analysis, we found that both $\mathrm{LTD}_{4}$ and montelukast did not influence the differentiation of Th1 (Figure 6A, 6B), Th17 (Figure 6C, 6D) or Treg (Figure 6E, 6F) in vitro. To exclude the possible that high dose of IL-12 may mask the effect of montelukast treatment, we titrated down the concentration of IL-12 for in vitro Th1 differentiation. Different dose of IL-12 were tried and there were no

\section{Serum EIA}

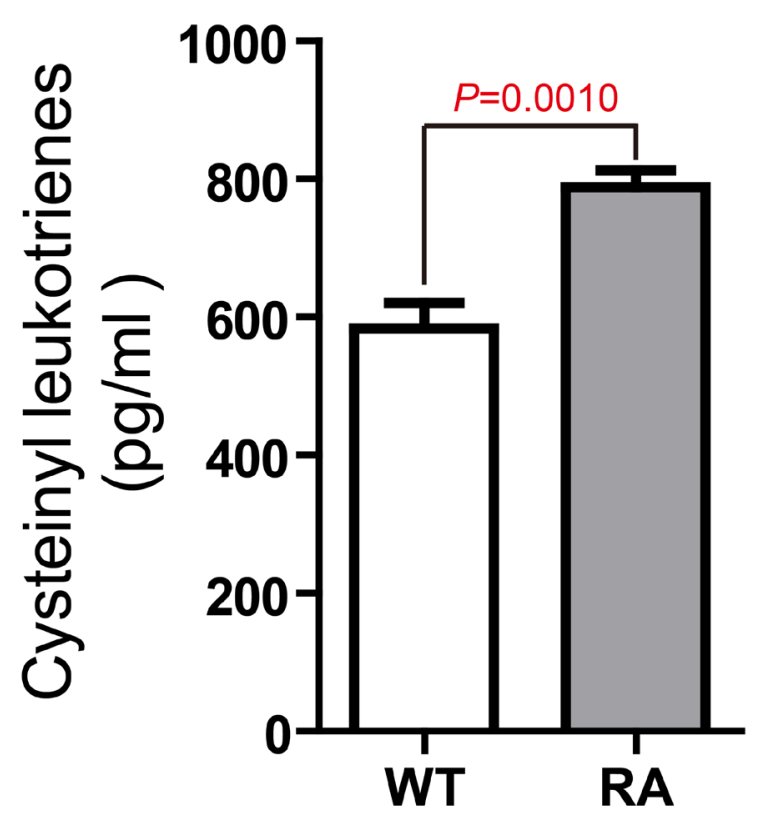

Figure 2: Significantly increased CysLTs levels in the serum of CIA mice. Total CysLTs concentrations in serum (6 weeks post booster immunization) were measured with an EIA kit. Data are presented as mean $\pm \operatorname{SEM}(n=3)$ and are representative of three independent experiments. ${ }^{*} p<0.05$, ** $p$ $<0.01$, versus control (Student's $t$-test). 


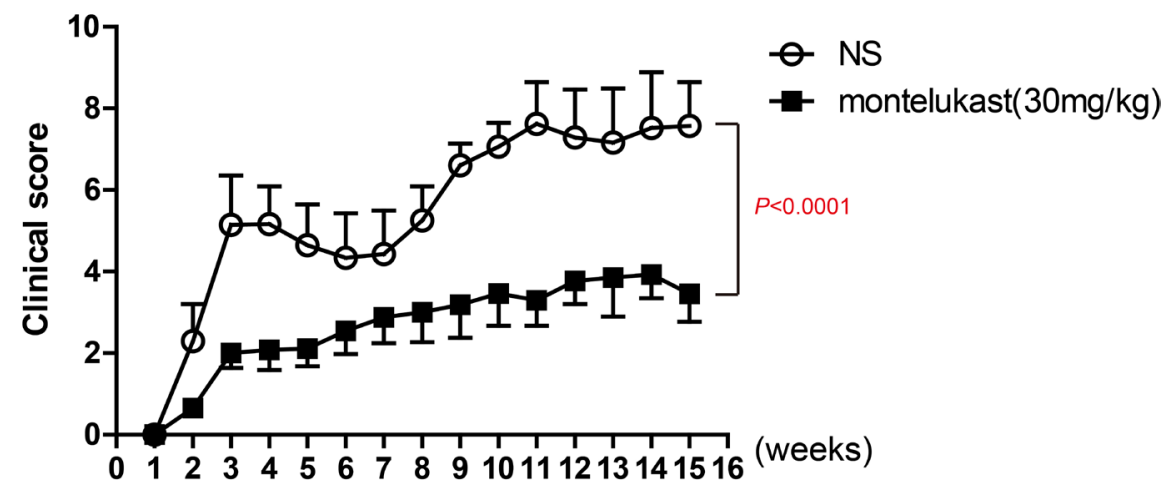

Figure 3: CysLT1 receptor antagonists alleviate pathogenesis of CIA. CIA was induced in male DBA mice by immunization with chicken type II collagen. Drugs (montelukast $30 \mathrm{mg} / \mathrm{kg} / \mathrm{d}$ ) were given once daily via i.p. injection from day 1 post booster immunization till the end of the study and clinical scores were recorded. Control groups were treated with $0.9 \%$ saline injections. Data are presented as mean \pm SEM $(\mathrm{n}=6)$ and are representative of three independent experiments. $* p<0.05, * * p<0.01$, versus vehicle control (Mann-Whitney test).

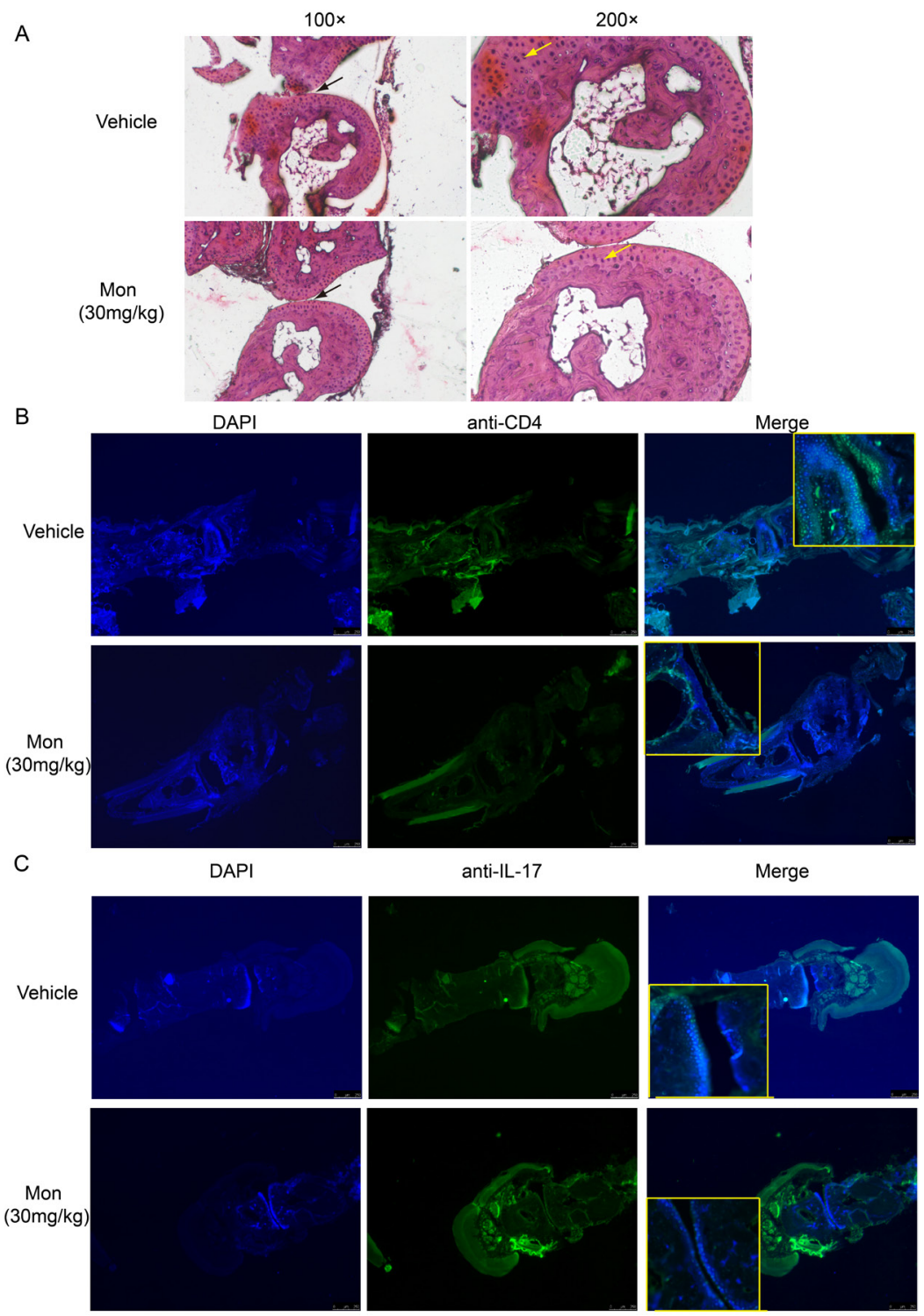

Figure 4: Montelukast treatment reduces pathogenic $\mathbf{T}$ cells in the hind paw. H\&E staining of paraffin sections of hind paw isolated from vehicle or montelukast $(30 \mathrm{mg} / \mathrm{kg}$, starting from day 1 post booster immunization) treated CIA mice. Black arrows indicate the bone changes, yellow arrows indicate the areas of Infiltration A. Immunofluorescent staining of CD4+ T cells B. and IL-17A+ T cells C. in the paraffin sections of hind paw isolated from vehicle or montelukast (30 mg/kg) treated CIA mice. 
A Vehicle

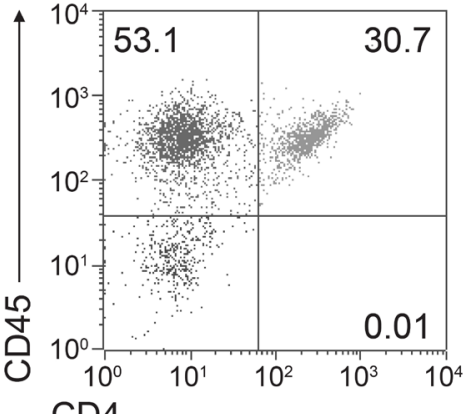

CD4

C

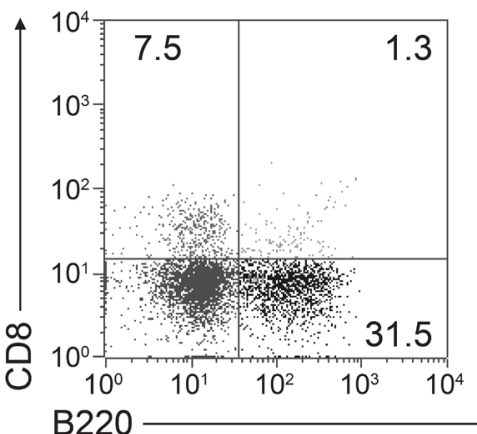

E

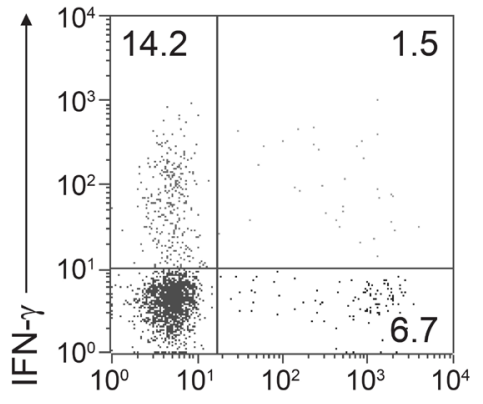

IL-17

G

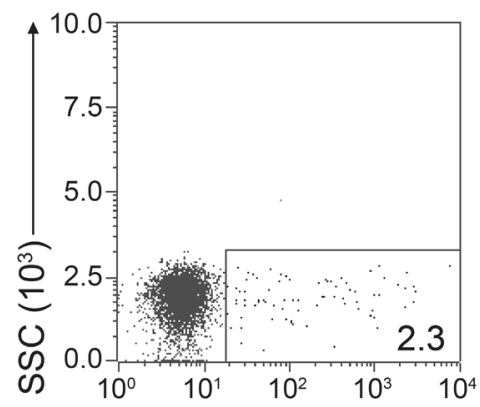

Foxp3

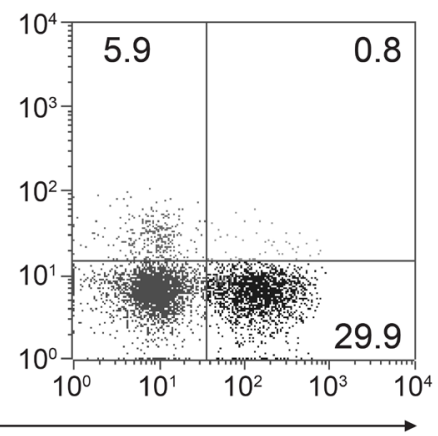

Montelukast
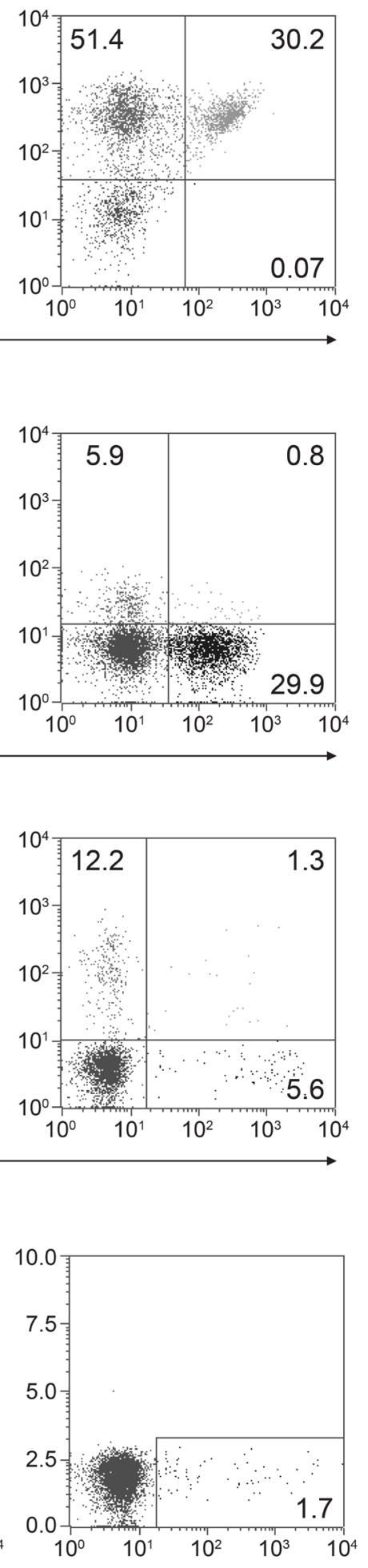

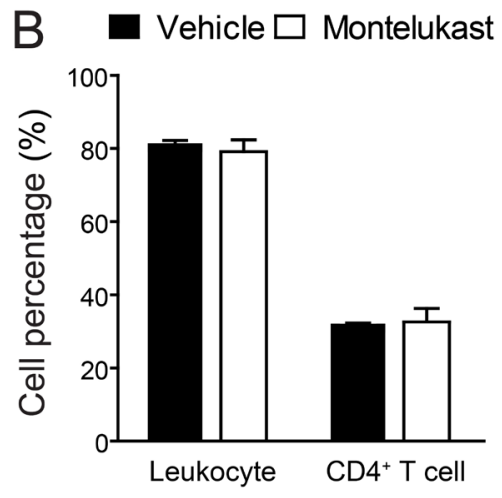

D

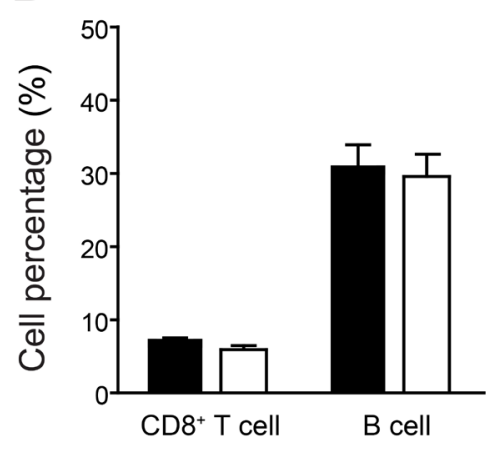

F

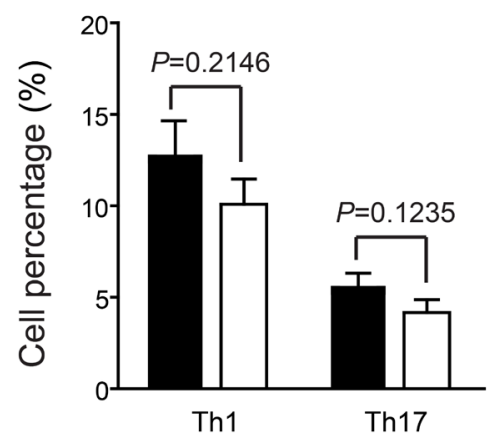

$\mathrm{H}$

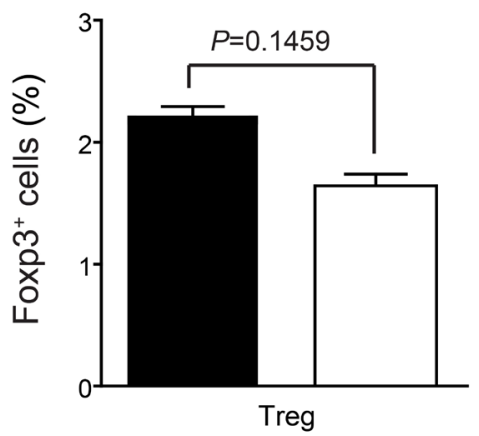

Figure 5: Montelukast treatment does not affect $T$ cell proliferation. Leukocytes in peripheral blood were isolated from CIA animals treated with montelukast $(30 \mathrm{mg} / \mathrm{kg}$ ) or vehicle control at weeks 9 post booster immunization and analyzed with flow cytometry. A.-D. Surface staining of CD $45^{+}$cells, CD4 ${ }^{+}$T cells, CD $8^{+}$T cells and B cells; E.-H. Th1, Th17 and Treg cells were analyzed by intracellular staining of IFN- $\gamma$, IL-17 and Foxp-3 respectively within the CD4 ${ }^{+}$gate. Data represents mean \pm SEM of three independent experiments. 
differences for in vitro Th1 differentiation (Supplementary Figure 11). Then we titrated down the concentration of montelukast during $\mathrm{CD}^{+} \mathrm{T}$ cells differentiation and there was indistinguishableness in different dose of montelukast (Supplementary Figure 12). Recently, T follicular helper (Tfh) cells have been researched as a new T helper lineage and were associated with auto-antibodies in CIA [26]. We checked the Tfh cells $\left(\mathrm{Bcl} 6^{+} \mathrm{CXCR} 5^{+} \mathrm{CD} 4^{+} \mathrm{T}\right.$ cells) in spleen and lymph nodes after treated with montelukast in CIA mice and we found that montelukast had no any effect in Tfh cells proportion and Tfh absolute cells number (Supplementary Figure 13). The preliminary results may indicate that montelukast had no effect on Tfh cells although more evidences were need.

\section{Montelukast decreased the secretion of IL-17A and the expression of $I L-17 A$ gene}

We are curious to learn whether montelukast can decreased the secretion of cytokines. The serum from CIA mice treated with vehicle or Montelukast was collected and the levels of IL-17A, IFN- $\gamma$, IL- $1 \beta$, TNF- $\alpha$ and TGF- $\beta$ were detected using specific ELISA Kits. As shown in Figure 7A and S14A, montelukast obviously inhibited the secretion of IL-17A. In contrast, the production of IFN- $\gamma$, IL- $1 \beta$, TNF- $\alpha$ and TGF- $\beta$ were not significantly affected by montelukast. Then we checked the levels of IL-17A, IFN- $\gamma$, IL- $1 \beta$, TNF- $\alpha$ and TGF- $\beta$ in hind paw. After homogenization, the hind paw supernatant was collected and the cytokines were tested. As shown in Figure 7B and Supplementary Figure 14B, montelukast obviously inhibited the secretion of IL-17A in hind paw. Still, there were no change in other cytokines. We then checked the expression levels of cytokines. The $I L-17 A$ mRNA of leukocytes in peripheral blood (Figure 8A) and lesions joints (Figure 8B) were significantly decreased at week 9 after treated with montelukast. In contrast, $I F N-\gamma, I L-1 \beta$, $T N F-\alpha$ and $T G F-\beta$ gene were not significantly altered in both vehicle and montelukast treated CIA mice (Figure 8A, 8B, Supplementary Figure 15).
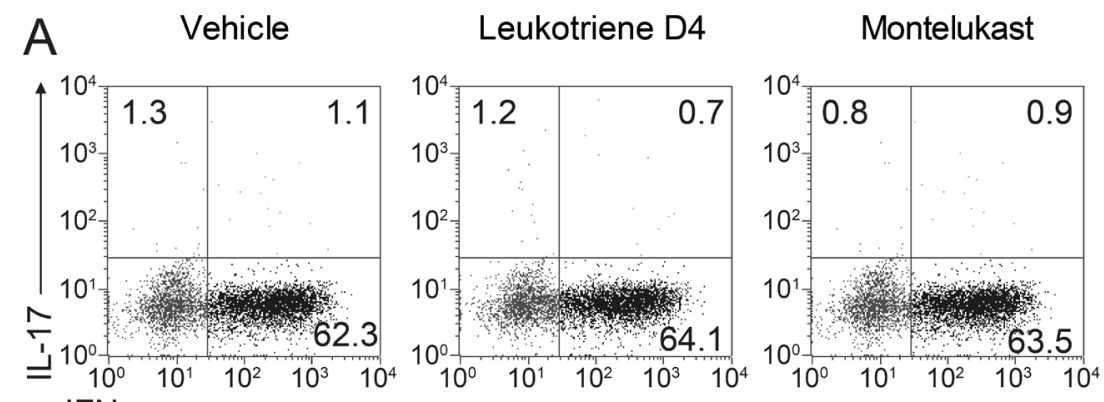

$$
\text { IFN- } \gamma
$$

\section{C}
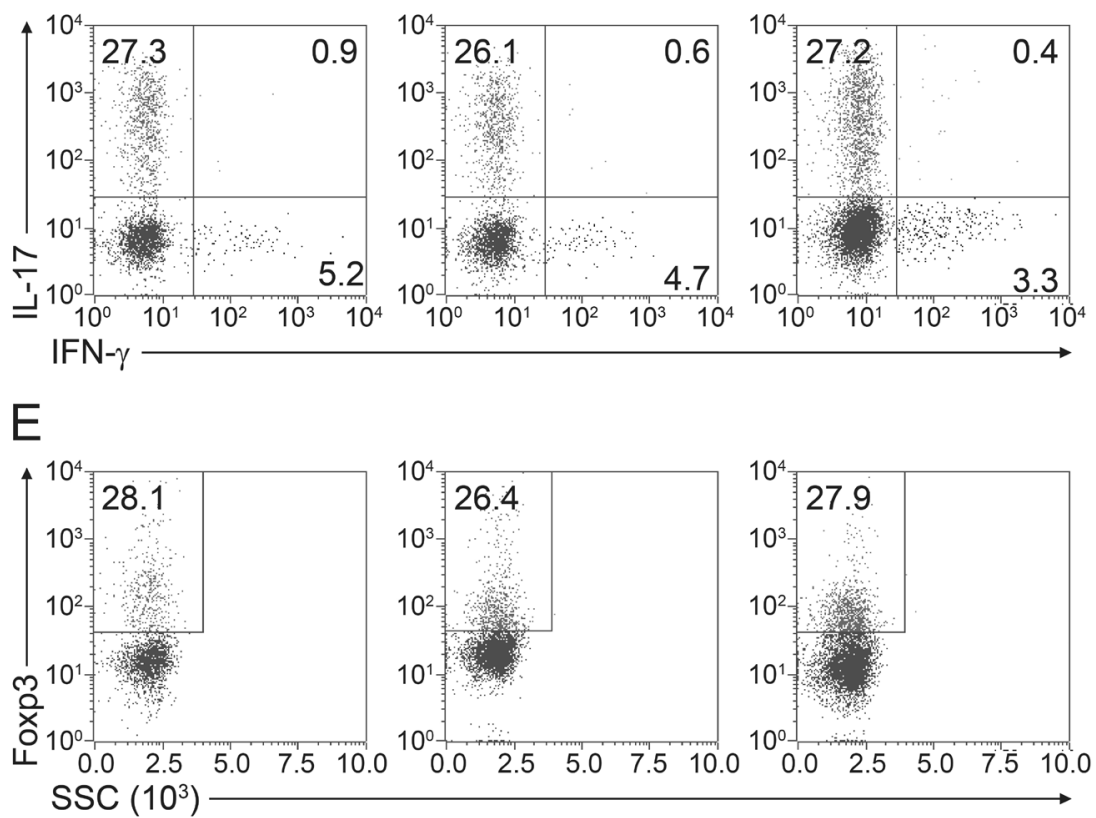

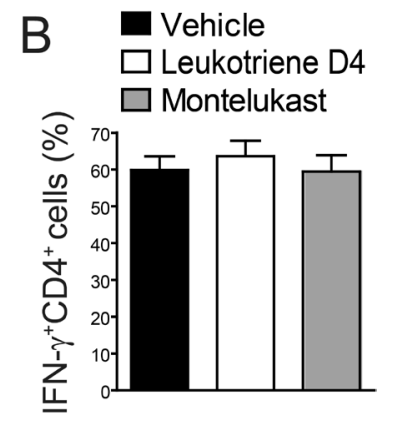

$\mathrm{D}$

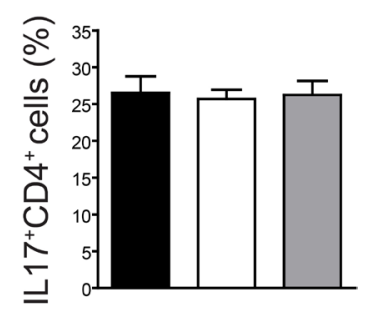

$\mathrm{F}$

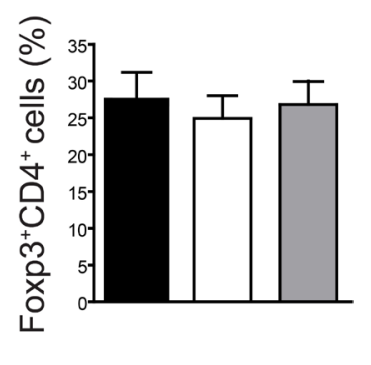

Figure 6: Montelukast treatment does not affect $\mathbf{T}$ cell differentiation. Naive $\mathrm{CD}^{+} \mathrm{T}$ cells isolated from spleen of 8-9 week-old naive mice were induced to differentiate into Th1 A., B. Th17 C., D., or Treg E., F. in vitro, in the presence of leukotriene $\mathrm{D}_{4}(100 \mu \mathrm{m})$ or montelukast $(100 \mu \mathrm{m})$. Data represents mean \pm SEM of three independent experiments. 
Taken together, we can draw a conclude that CysLT1 signaling pathway is not participate in the differentiation or proliferation of inflammatory $\mathrm{T}$ cells or regulatory $\mathrm{T}$ cells, but might affect the cytokine secretion, gene expression in Th17 cells and infiltration of pathogenic $\mathrm{T}$ cells.

\section{DISCUSSION}

As a systemic autoimmune disease, RA is characterized by immune-mediated synovitis, local inflammatory cells infiltration and neoangiogenesis. Due to insufficient understanding of the pathogenesis of RA, there are still many obstacles in the treatment of RA, and new therapeutic targets need to be determined [27]. As one of the biggest receptor super-family, GPCRs widely take part in all kinds of biological activities and participate deeply in several kinds of diseases [28]. Because of its significance biological function and cell surface localization, GPCRs are the most targeted macromoleculars on the clinical medicine [29]. Recently, SCH-23390, a D1-like receptor antagonist, has been demonstrated to inhibit cartilage destruction [30]. This study showed that dopamine level was obviously increased in RA synovial fluid, dopamine could increase IL-17 secretion via D1-like receptors which was IL-6 depended. In a RA mouse model, SCH-23390 intensively decreased the aggregation of IL- $6^{+}$and IL-17 $7^{+}$ $\mathrm{T}$ cells with alleviated cartilage destruction. This study assesses the role of a D1-like receptors in the pathogenesis of Th17-mediated autoimmune disease, RA. Another report showed that dopamine D2 receptor was expressed on B cells in RA synovial tissue, which has been found to be negatively correlated with the levels of TNF- $\alpha$ and with clinical manifestation [31]. Other GPCRs may also be associated with RA, including sphingosine 1-phosphate (S1P) receptor [32, 33], A3 adenosine receptor [34, 35] , A2A adenosine receptors [36], purinergic receptor P2X4 [37] and many chemokine receptors [38-41]. Here we find that in CIA mice, CysLT1 signaling pathway, including CysLT1, cPLA2 $\alpha$ and 5-LO, are involved in the pathogenesis of RA. Montelukast, CysLT1 antagonists, could effectively alleviate the condition of RA.

Numerous studies have shown that CysLT1 signaling pathway are widely involved in the of respiratory diseases and inflammatory diseases, while their role in autoimmune diseases are rarely explored. Our reports had previously
A

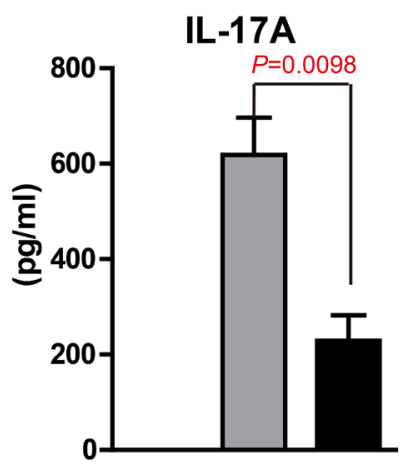

B

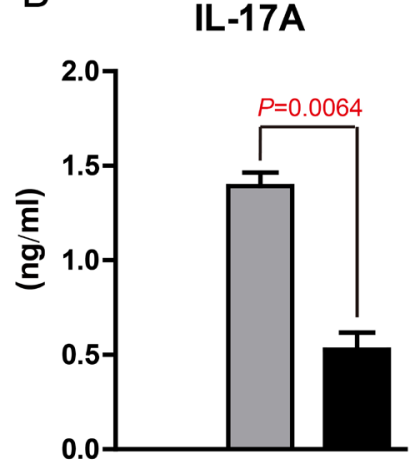

IFN-Y

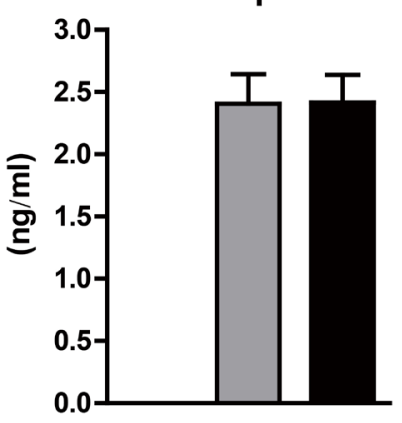

IFN-Y

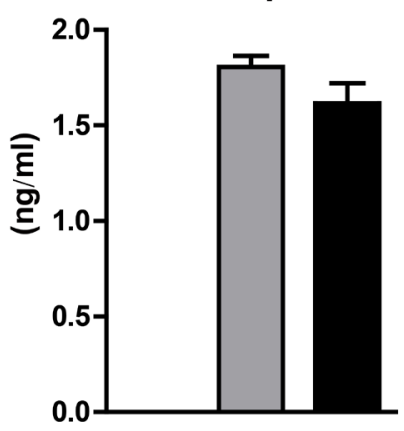

IL-1 $\beta$

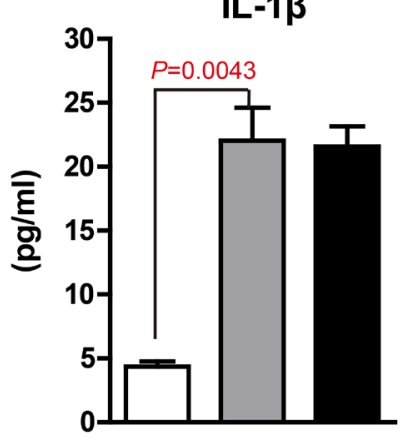

IL-1 $\beta$

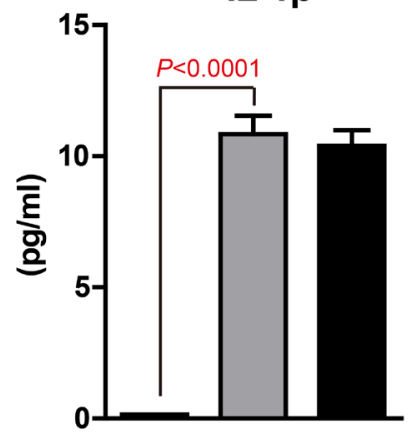

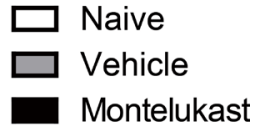

$(30 \mathrm{mg} / \mathrm{kg})$

Figure 7: Montelukast decreased the production of IL-17A in CIA mice. naive and CIA mice treated with vehicle or Montelukast serum A. and homogenate supernatant B. were collected and the amounts of IL-17A, IFN- $\gamma$, IL-1 $\beta$ and TGF- $\beta$ were determined using specific ELISA. Data are presented as mean $\pm \operatorname{SEM}(n=3)$ and are representative of three independent experiments. ${ }^{*} p<0.05, * * p<0.01$, versus control (Student's $t$-test). 
indicated that CysLT1 signaling pathway participated in experimental autoimmune encephalomyelitis (EAE) pathogenesis, blocking CysLT1 signaling pathway with montelukast could effectively ameliorate clinical symptoms of EAE [22].

Then we wondered that whether the CysLTs signaling can also involve in the pathogenesis of RA. Our study indicated that in CIA animals, the synthesizing enzymes, cPLA2 $\alpha$ and 5-LO were up-regulated and LTC4S had no significant change. Meanwhile, the expression level of signaling receptor, CysLT1, was significant upregulated. To confirm the relationship of CysLTs signaling with CIA, we checked the ligand levels and found that CysLTs were also higher in CIA than in control mice.

We then detected the effects of CysLT1 antagonist on CIA mice. We found that montelukast, targeted CysLT1, effectively ameliorated clinical symptoms, while CysLT1 signaling did not participate in the proliferation and differentiation of $\mathrm{T}$ helper cells, though the trends of decrease could be observed. Plenty of studies indicated that CysLT1 signaling might affect the pathogenesis of disease by inducing chemotaxis of $\mathrm{T}$ cells [42-44], our result showed that obvious infiltration of pathogenic $\mathrm{T}$ cells in CIA mice can be blocked by CysLT1 antagonists.

Since the Th17 cells and IL-17 have been shown a momentous role in the pathogenesis of CIA, we then tested the cytokine expression level in serum and in lesions joints. The results showed that an increased IL-17 production in serum and hind paw of CIA mice and the gene expression were decreased after treated with CysLT1 antagonist.

Taken together, our findings indicate that the CysLT1 signaling pathway participates in the pathogenesis of CIA and it will alleviate the disease symptoms of CIA after blocking the CysLTs signaling pathways. These results not only reveal the pathogenesis of CIA, but also provide a novel therapeutic target for the treatment of RA.

A

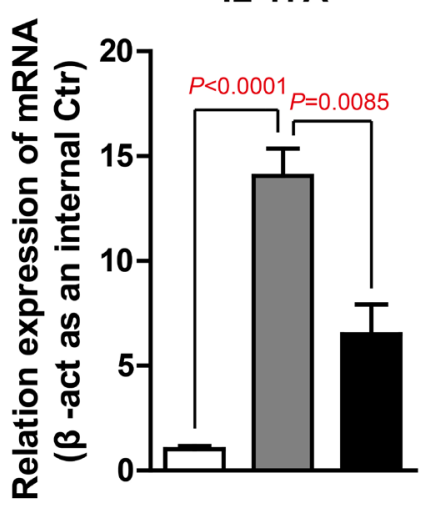

B IL-17A

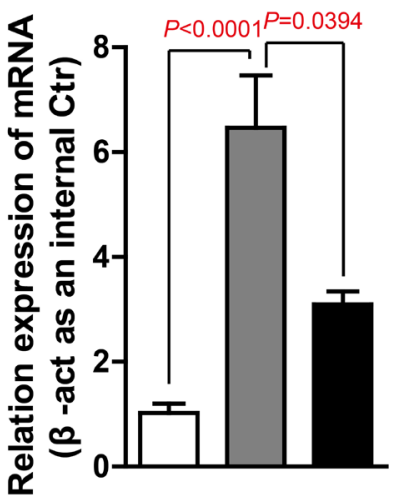

IFN-y

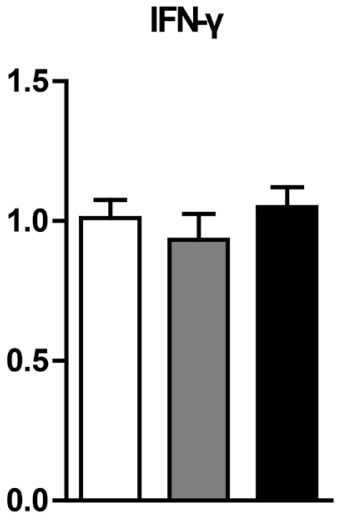

IFN-Y

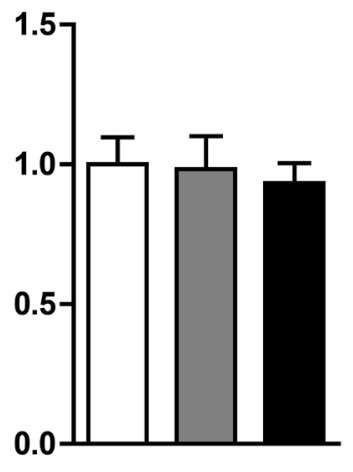

IL-1 $\beta$

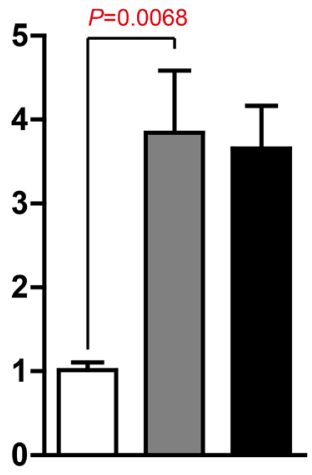

IL-1 $\beta$

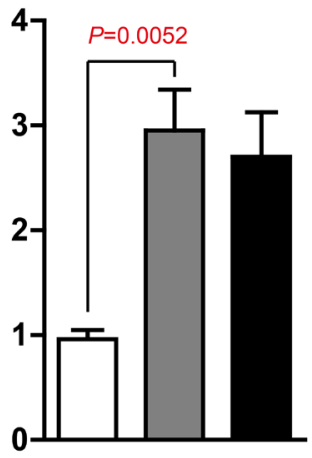

Naive

Vehicle

Montelukast (30 mg/kg)

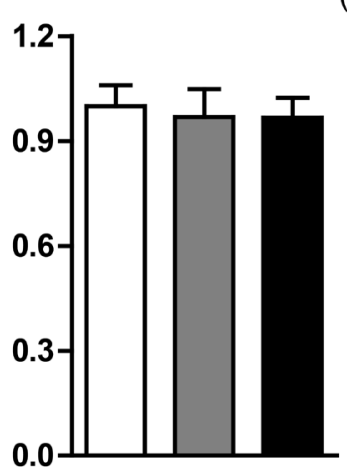

TGF- $\beta$

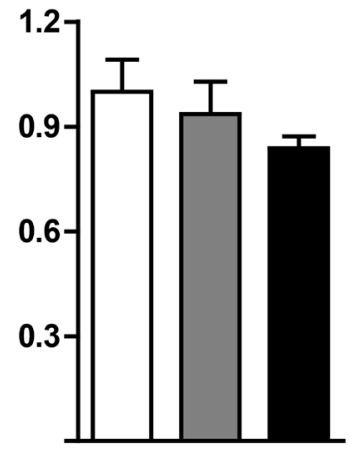

Figure 8. Montelukast down-regulate the expression of IL-17A gene in CIA mice. A. Leukocytes in peripheral blood were isolated from naive mouse, CIA animals treated with montelukast $(30 \mathrm{mg} / \mathrm{kg})$ or vehicle control at weeks 9 post booster immunization, IL-17A, IFN- $\gamma$, $I L-1 \beta$ and $T G F-\beta$ gene are analyzed by qPCR. B. Hind paw of naive mouse, CIA animals treated with montelukast $(30 \mathrm{mg} / \mathrm{kg})$ or vehicle control at weeks 9 post booster immunization homogenate. RNA was isolated and $I L-17 A, I F N-\gamma, I L-1 \beta$ and $T G F-\beta$ gene are analyzed by qPCR. Data are presented as mean $\pm \operatorname{SEM}(n=3)$ and are representative of three independent experiments $\left(. *^{*} p<0.05, * * p<0.01\right.$, versus control (two-way ANOVA test). 


\section{MATERIALS AND METHODS}

\section{Animals}

Male DBA mice were purchased from Shanghai Laboratory Animal Centre (Shanghai, China). All mice were housed in the Gannan medical University animal care facility and were maintained in pathogen-free conditions. Mice were 7-9 weeks old at the initiation of the experiment and were maintained on standard laboratory chow and water ad libitum. All experiments were approved and conducted in accordance with the guidelines of the Animal Care Committee of Gannan medical University.

\section{Reagents}

Montelukast were from Merck. M-MLV Reverse Transcriptase and RNasin Ribonuclease inhibitor were from Promega (Fitchburg, WI). SYBR Green JumpStart ${ }^{\mathrm{TM}}$ Taq ReadyMixTM kit and sodium fluorescein were from Sigma (St.Louis, MO). Fluorescein isothiocyanate (FITC) anti-mouse CD45, FITC anti-mouse CD8a, phycoerythrin (PE) anti-mouse CD45R (B220) and APC anti-mouse/rat Foxp3 staining set were purchased from eBioscience (San Diego, CA). PE-Cy7 anti-mouse CD4, PE anti-mouse IL17A, APC anti-mouse IFN- $\gamma$, PE anti-mouse Foxp3 and BD Cytofix/Cytoperm kit were purchased from BD bioscience (Franklin Lakes,NJ). IL-17A, IFN- $\gamma$, TGF- $\beta$, TNF- $\alpha$, IL-1 $\beta$ ELISA kit were from Dakewe (Shenzhen, China).

\section{CIA induction and drug treatment}

Chicken type II collagen was dissolved in $0.05 \mathrm{M}$ aceticacid at a concentration of $2 \mathrm{mg} / \mathrm{ml}$ by stirring overnight at $4{ }^{\circ} \mathrm{C}$ and was then emulsified in an equal volume of CFA. Collagen $(100 \mu \mathrm{g})$ was injected intradermally at the base of the tail and boost at day 21. CIA was scored from day 1 post booster using a scale of $0-4$ per limb, where $0=$ no swelling or redness, $1=$ swelling or redness in 1 digit, 2 =mild swelling and redness involving the entire paw, $3=$ moderate swelling and redness involving the entire paw, and $4=$ severe swelling and redness involving the entire paw. For drug treatment, montelukast was injected intraperitoneally (30 $\mathrm{mg} / \mathrm{kg}$ body weight in saline) once daily from day 1 post booster till the end of the study. Saline was given as a vehicle control (100 $\mu \mathrm{l}$ for each mouse).

\section{Histopathological and immunofluorescent analysis}

For analysis of drug effects, hind paw was collected after PBS perfusion. For histological staining, mice were anesthetized and perfused with PBS ( $\mathrm{pH}$ 7.4) followed by $4 \%(\mathrm{w} / \mathrm{v})$ paraformaldehyde. Tissue samples were then fixed in $4 \%(\mathrm{w} / \mathrm{v})$ paraformaldehyde overnight and then decalcified for 7 days with 15\% EDTA-2Na, embedded in paraffin. Section of hind paw were stained with hematoxylin and eosin for analysis of inflammation, respectively. Sections of hind paw were stained with antimouse CD4 antibody and anti-mouse IL-17 antibody (BioLegend) and followed with appropriate fluorescentlabeled secondary antibody.

\section{Reverse transcription and real-time PCR}

Total RNA was extracted from mouse tissues using TRIzol (Invitrogen) according to the manufacturer's instructions. The RNA was subjected to reverse transcription with random hexamer primer and M-MLV Reverse Transcriptase (Progema). Real-time PCR was conducted in the LightCycler quantitative PCR apparatus (Stratagene) using the SYBR Green JumpStart ${ }^{\mathrm{TM}}$ Taq ReadyMix ${ }^{\mathrm{TM}}$ kit (Sigma). Expression values were normalized to $\beta$-Actin. The primer pairs used are as follows: CysLT1 senseCTCCAAGGCACCAAGCAGAC, CysLT1 antisense- TGCCAAAGAAACCCACAACAG; 5-LO sense- CACGCATCTGGTGTCTGAGG, 5-LO antisense- CCTTAGTGTTGATAGCAATGGTGA; cPLA2 $\alpha$ sense- GACAGCAGGAAGCGAACGAGAC, cPLA2 $\alpha$ anti-sense-CGTAGTTGGCATCCATCAGTGTGA,

LTC4S sense- CCTGTGCGGACTGTTCTACCT, LTC4S anti-sense- GCCATCGCCACCAGCA; $\beta$-actin sense- GGCTGTATTCCCCTCCATCG, $\beta$-actin antisense- CCAGTTGGTAACAATGCCATGTT; IL17A sense- TTAACTCCCTTGGCGCAAAA; IL$17 \mathrm{~A}$ antisense- CTTTCCCTCCGCATTGACAC; TGF- $\beta$ sense-CTCCCGTGGCTTCTAGTGCT; TGF- $\beta$ antisense-AGCCTTAGTTTGGACAGGATCTG;

IFN- $\gamma$ sense- ACAATGAACGCTACACACTGCAT; IFN- $\gamma$ antisense-CCTTTTGCCAGTTCCTCCAG; IL$1 \beta$ sense- AAGCCTCGTGCTGTCGGA; IL-1ßantisenseCAGGGTGGGTGTGCCGT

\section{Cysteinyl leukotriene EIA}

The CysLTs in serum were quantified by using a competitive enzyme immunoassay (EIA, Cayman chemical), according to the manufacturer's instructions. Orbital blood was collected and incubated at $4^{\circ} \mathrm{C}$ for 30 min and serum was collected after $10 \mathrm{~min}$ centrifugation at $4500 \mathrm{~g}$. hind paw and lymph node homogenate supernatant were collected after $10 \mathrm{~min}$ centrifugation at $12000 \mathrm{~g}$. data were calculated as pg or ng of CysLTs per ml liquid and then normalized to the naïve mice. 


\section{$\mathrm{CD4}^{+} \mathrm{T}$ cell separation and in vitro differentiation}

Naive $\mathrm{CD} 4^{+} \mathrm{T}$ cells were prepared by magnetic cell separation (invitrogen) from spleens of male DBA mice $8-9$ weeks of age. Separated cells were activated with anti-CD3 (2 $\mu \mathrm{g} / \mathrm{ml} ; 145-2 \mathrm{C} 11$, soluble; BD Pharmingen) and anti-CD28 (2 $\mu \mathrm{g} / \mathrm{ml} ; 37.51$, soluble; BD Pharmingen $)$ and were induced to differentiate into Th1 cells by supplementation with IL-12 (10 ng/ml; Peprotech) and anti-IL-4; or into inducible Treg cells with TGF- $\beta 1$ (5 ng/ml; Peprotech), recombinant mouse IL-2 (50 U/ml; Peprotech) and anti-IFN- $\gamma$. For Th17 differentiation, cells received anti-IL-4 and anti-IFN- $\gamma$ plus a Th17 'cocktail' containing TGF- $\beta 1$ ( $3 \mathrm{ng} / \mathrm{ml})$, IL-6 (30 ng/ml; eBioscience), tumor necrosis factor $(10 \mathrm{ng} / \mathrm{ml}$; Peprotech) and IL-1 $\beta$ (10 ng/ml; Peprotech). Neutralizing anti-IFN- $\gamma$ (XMG1.2; BD Pharmingen) and anti-IL-4 (11B11; BD Pharmingen) were each used at a concentration of $10 \mu \mathrm{g} /$ $\mathrm{ml}$. Compounds at various concentrations were added with the cytokine cocktail to assess their influence on T cell differentiation.

\section{Flow cytometry}

Splenocytes or leukocytes in peripheral blood were incubated for $5 \mathrm{hr}$ at $37^{\circ} \mathrm{C}$ with phorbol 12-myristate 13 -acetate $(50 \mathrm{ng} / \mathrm{ml}$; Sigma), ionomycin $(750 \mathrm{ng} / \mathrm{ml}$; Sigma) and brefeldin A $(1.0 \mu \mathrm{g} / \mathrm{ml}$; Sigma). Surface markers were stained with relevant antibodies. After surface staining, cells were re-suspended in fixation/ permeabilization solution (Cytofix/Cytoperm kit; BD Pharmingen) and intracellular cytokine staining was done according to the manufacturer's protocol. For Foxp3 staining, cells were not stimulated with phorbol 12-myristate 13-acetate and ionomycin; instead, the protocol for the Foxp3 Staining Buffer set was followed the manufacturer's instructions (eBioscience). Data was acquired using a BD LSRII Flow Cytometer (BD Bioscience) and analyzed using FlowJo software (Tree Star).

\section{ELISA}

Control or CIA mice treated with vehicle or montelukast, respectively were sacrificed at week 9 or 12 post booster immunization. The serum was collected and the hind paw through tissue homogenization. Supernatants were collected. The cytokines (IL-17A, IFN- $\gamma$, TNF- $\alpha$, IL-1 $\beta$ and TGF- $\beta$ ) in serum and in supernatant were determined using specific ELISA Kits (Dakewe, Shenzhen, China), according to the manufacturer's instructions.

\section{CFSE staining}

T cells were labelled with $5 \mu \mathrm{m}$ CFSE (Invitrogen, CA, USA) at $37{ }^{\circ} \mathrm{C}$ for $10 \mathrm{~min}$. Then, the cells were thoroughly washed with $1 \% \mathrm{FBS} / \mathrm{PBS}$ to remove the excess dye according to the manufacturer instructions. Labeled cells were seeded $\left(5 \times 10^{5}\right)$ in 6 well plates and cultured for 72 hours in a $37^{\circ} \mathrm{C}$ humidified atmosphere with $5 \% \mathrm{CO}_{2}$. Data was acquired using a BD LSRII Flow Cytometer (BD Bioscience) and analyzed using FlowJo software (Tree Star).

\section{Western blot}

Cells were washed once with PBS, lysed in lysis buffer $(50 \mathrm{mM}$ Tris [pH 7.4], $150 \mathrm{~mm} \mathrm{NaCl}, 0.1 \%$ CHAPS, $1 \mathrm{~mm}$ EDTA, $1 \mathrm{~mm} \mathrm{NaF,} 1 \mathrm{~mm} \mathrm{Na} \mathrm{VO}_{3}$, and protease inhibitors) by sonication for 30 s on ice. Protein concentrations were determined by the BCA method (Thermo Scientific). Equal amounts of protein samples were subjected to SDS-PAGE and then transferred onto polyvinylidene difluoride membranes (Millipore). Western blotting was performed using the mouse anti-Bcl-2, antiCaspase-3 and corresponding HRP-conjugated secondary $\mathrm{Ab}$ (Promega)

\section{Statistical analysis}

Data are presented as mean \pm SEM. The statistical significance of the CIA clinical scores between treatments was analyzed with two-way ANOVA test. And the CIA scores at a given date were analyzed by Mann-Whitney test. Other analyses, including gene expression, cytokine production, were assessed by Student's t-test or twoway ANOVA test. $p<0.05$ was considered statistically significant.

\section{Author contributions}

Author contributions: MinWen Xu performed the experiments, analyzed data and prepared Supplementary Figure and manuscript; Ruiyun Hong, Xiaoli Zhang, Hailin Zou, Yi Zhang, Zhiping Hou performed the experiments. LieFeng Wang designed overall the research project, performed part of hands-on work, analyzed data, prepared Supplementary Figure, and wrote the manuscript.

\section{ACKNOWLEDGMENTS}

This work was partially supported by the National Natural Science Foundation of China (31260279 and 31660256) to Wang, the Science and Technology Project Foundation of Education Department of Jiangxi 
Provincial (GJJ150961) to $\mathrm{Xu}$, the Higher Education Foundation of Jiangxi Provincial (KJLD2090) to Wang, the Natural Science Foundation of Jiangxi Province (20132BAB205032) to Wang, and the Natural Science Foundation of Gannan Medical University (201103,201201, ZD201103, YC201502) to Wang.

\section{CONFLICTS OF INTEREST}

We have no competing financial interests.

\section{REFERENCES}

1. Zhou RP, Wu XS, Xie YY, Dai BB, Hu W, Ge JF, Chen FH. Functions of interleukin-34 and its emerging association with rheumatoid arthritis. Immunology. 2016; 149:362-73.

2. Guo W, Yu D, Wang X, Luo C, Chen Y, Lei W, Wang C, Ge Y, Xue W, Tian Q, Gao X, Yao W. Anti-inflammatory effects of interleukin-23 receptor cytokine-binding homology region rebalance $\mathrm{T}$ cell distribution in rodent collagen-induced arthritis. Oncotarget. 2016; 7:31800-13. https://doi.org/10.18632/oncotarget.9309.

3. Zhu SL, Huang JL, Peng WX, Wu DC, Luo MQ, Li QX, Li ZX, Feng XX, Liu F, Wang MX, Chen WQ, Olsen N, Zheng SG. Inhibition of smoothened decreases proliferation of synoviocytes in rheumatoid arthritis. Cell Mol Immunol. 2017; 14:214-22.

4. Zhang Q, Wu J, Cao Q, Xiao L, Wang L, He D, Ouyang G, Lin J, Shen B, Shi Y, Zhang Y, Li D, Li N. A critical role of Cyr61 in interleukin-17-dependent proliferation of fibroblast-like synoviocytes in rheumatoid arthritis. Arthritis Rheum. 2009; 60:3602-3612.

5. Schminke B, Trautmann S, Mai B, Miosge N, Blaschke S. Interleukin 17 inhibits progenitor cells in rheumatoid arthritis cartilage. Eur J Immunol. 2016; 46:440-445.

6. Rohn TA, Jennings GT, Hernandez M, Grest P, Beck M, Zou Y, Kopf M, Bachmann MF. Vaccination against IL-17 suppresses autoimmune arthritis and encephalomyelitis. Eur J Immunol. 2006; 36:2857-2867.

7. Zrioual S, Toh ML, Tournadre A, Zhou Y, Cazalis MA, Pachot A, Miossec V, Miossec P. IL-17RA and IL$17 \mathrm{RC}$ receptors are essential for IL-17A-induced ELR+ CXC chemokine expression in synoviocytes and are overexpressed in rheumatoid blood. J Immunol. 2008; 180:655-663.

8. Park MJ, Park HS, Oh HJ, Lim JY, Yoon BY, Kim HY, Cho ML, Cho SG. IL-17-deficient allogeneic bone marrow transplantation prevents the induction of collagen-induced arthritis in DBA/1J mice. Exp Mol Med. 2012; 44:694-705.

9. Kugyelka R, Kohl Z, Olasz K, Mikecz K, Rauch TA, Glant TT, Boldizsar F. Enigma of IL-17 and Th17 Cells in Rheumatoid Arthritis and in Autoimmune Animal Models of Arthritis. Mediators Inflamm. 2016; 2016:6145810.

10. Kumari P, Ghosh E, Shukla AK. Emerging Approaches to
GPCR Ligand Screening for Drug Discovery. Trends Mol Med. 2015; 21:687-701.

11. Jacobson KA. New paradigms in GPCR drug discovery. Biochem Pharmacol. 2015; 98:541-555.

12. Neumann E, Khawaja K, Muller-Ladner U. G proteincoupled receptors in rheumatology. Nat Rev Rheumatol. 2014; 10:429-436.

13. Vega B, Calle A, Sanchez A, Lechuga LM, Ortiz AM, Armelles G, Rodriguez-Frade JM, Mellado M. Real-time detection of the chemokine CXCL12 in urine samples by surface plasmon resonance. Talanta. 2013; 109:209-215.

14. Lee EY, Seo M, Juhnn YS, Kim JY, Hong YJ, Lee YJ, Lee EB, Song YW. Potential role and mechanism of IFNgamma inducible protein-10 on receptor activator of nuclear factor kappa-B ligand (RANKL) expression in rheumatoid arthritis. Arthritis Res Ther. 2011; 13:R104.

15. Hay DW, Torphy TJ, Undem BJ. Cysteinyl leukotrienes in asthma: old mediators up to new tricks. Trends Pharmacol Sci. 1995; 16:304-309.

16. Machida I, Matsuse H, Kondo Y, Kawano T, Saeki S, Tomari S, Obase Y, Fukushima C Kohno S. Cysteinyl leukotrienes regulate dendritic cell functions in a murine model of asthma. J Immunol. 2004; 172:1833-1838.

17. Allayee H, Hartiala J, Lee W, Mehrabian M, Irvin CG, Conti DV, Lima JJ. The effect of montelukast and lowdose theophylline on cardiovascular disease risk factors in asthmatics. Chest. 2007; 132:868-874.

18. Stanke-Labesque F, Pofelski J, Moreau-Gaudry A, Bessard G, Bonaz B. Urinary leukotriene E4 excretion: a biomarker of inflammatory bowel disease activity. Inflamm Bowel Dis. 2008; 14:769-774.

19. Tantisira KG, Drazen JM. Genetics and pharmacogenetics of the leukotriene pathway. J Allergy Clin Immunol. 2009; 124:422-427.

20. Du C, Xie X. G protein-coupled receptors as therapeutic targets for multiple sclerosis. Cell Res. Cell Res. 2012; 22:1108-28.

21. Kihara Y, Yokomizo T, Kunita A, Morishita Y, Fukayama M, Ishii S, Shimizu T. The leukotriene B4 receptor, BLT1, is required for the induction of experimental autoimmune encephalomyelitis. Biochem Biophys Res Commun. 2010; 394:673-678.

22. Wang L, Du C, Lv J, Wei W, Cui Y, Xie X. Antiasthmatic drugs targeting the cysteinyl leukotriene receptor 1 alleviate central nervous system inflammatory cell infiltration and pathogenesis of experimental autoimmune encephalomyelitis. J Immunol. 2011; 187:2336-2345.

23. McGovern T, Goldberger M, Chen M, Allard B, Hamamoto Y, Kanaoka Y, Austen KF, Powell WS, Martin JG. CysLT1 Receptor Is Protective against Oxidative Stress in a Model of Irritant-Induced Asthma. J Immunol. 2016; 197:266-277.

24. Gonca E. The effects of zileuton and montelukast in reperfusion-induced arrhythmias in anesthetized rats. Curr Ther Res Clin Exp. 2013; 75:27-32. 
25. Li J, Yang P, Wu Q, Li H, Ding Y, Hsu HC, Spalding DM, Mountz JD. Death receptor 5-targeted depletion of interleukin-23-producing macrophages, Th17, and Th1/17 associated with defective tyrosine phosphatase in mice and patients with rheumatoid arthritis. Arthritis Rheum. 2013; 65:2594-2605.

26. Liu R, Li X, Zhang Z, Zhou M, Sun Y, Su D, Feng X, Gao X, Shi S, Chen W, Sun L. Allogeneic mesenchymal stem cells inhibited $\mathrm{T}$ follicular helper cell generation in rheumatoid arthritis. Sci Rep. 2015; 5:12777.

27. Bandeira-Melo C, Hall JC, Penrose JF, Weller PF. Cysteinyl leukotrienes induce IL-4 release from cord bloodderived human eosinophils. J Allergy Clin Immunol. 2002; 109:975-979.

28. Jalink K, Moolenaar WH. G protein-coupled receptors: the inside story. BioEssays. 2010; 32:13-16.

29. Pesut D, Raskovic S, Tomic-Spiric V, Bulajic M, Bogic M, Bursuc B, Peric-Popadic A. Gender differences revealed by the Brief Illness Perception Questionnaire in allergic rhinitis. Clin Respir J. 2014; 8:364-368.

30. Nakano K, Yamaoka K, Hanami K, Saito K, Sasaguri Y, Yanagihara N, Tanaka S, Katsuki I, Matsushita S, Tanaka Y. Dopamine induces IL-6-dependent IL-17 production via D1-like receptor on CD4 naive T cells and D1-like receptor antagonist SCH-23390 inhibits cartilage destruction in a human rheumatoid arthritis/SCID mouse chimera model. J Immunol. 2011; 186:3745-3752.

31. Wei L, Sun Y, Kong XF, Zhang C, Yue T, Zhu Q, He DY, Jiang LD. The effects of dopamine receptor 2 expression on B cells on bone metabolism and TNF-alpha levels in rheumatoid arthritis. BMC Musculoskelet Disord. 2016; 17:352.

32. Takeshita H, Kitano M, Iwasaki T, Kitano S, Tsunemi S, Sato C, Sekiguchi M, Azuma N, Miyazawa K, Hla T, Sano H. Sphingosine 1-phosphate (S1P)/S1P receptor 1 signaling regulates receptor activator of NF-kappaB ligand (RANKL) expression in rheumatoid arthritis. Biochem Biophys Res Commun. 2012; 419:154-159.

33. Graler MH. Targeting sphingosine 1-phosphate (S1P) levels and S1P receptor functions for therapeutic immune interventions. Cell Physiol Biochem. 2010; 26:79-86.

34. Ochaion A, Bar-Yehuda S, Cohen S, Barer F, Patoka R, Amital H, Reitblat T, Reitblat A, Ophir J, Konfino I, Chowers Y, Ben-Horin S, Fishman P. The antiinflammatory target $\mathrm{A}(3)$ adenosine receptor is overexpressed in rheumatoid arthritis, psoriasis and Crohn's disease. Cell Immunol. 2009; 258:115-122.

35. Fishman $\mathrm{P}$, Cohen $\mathrm{S}$. The $\mathrm{A} 3$ adenosine receptor (A3AR): therapeutic target and predictive biological marker in rheumatoid arthritis. Clin Rheumatol. 2016; 35:2359-2362.
36. Vincenzi F, Padovan M, Targa M, Corciulo C, Giacuzzo S, Merighi S, Gessi S, Govoni M, Borea PA, Varani K. $\mathrm{A}(2 \mathrm{~A})$ adenosine receptors are differentially modulated by pharmacological treatments in rheumatoid arthritis patients and their stimulation ameliorates adjuvant-induced arthritis in rats. PLoS One. 2013; 8:e54195.

37. Klein K, Aeschlimann A, Jordan S, Gay R, Gay S, Sprott H. ATP induced brain-derived neurotrophic factor expression and release from osteoarthritis synovial fibroblasts is mediated by purinergic receptor P2X4. PLoS One. 2012; 7:e36693.

38. Li N, Wei W, Yin F, Chen M, Ma TR, Wu Q, Zhou JR, Zheng SG, Han J. The abnormal expression of CCR4 and CCR6 on Tregs in rheumatoid arthritis. Int J Clin Exp Med. 2015; 8:15043-15053.

39. Talbot J, Bianchini FJ, Nascimento DC, Oliveira RD, Souto FO, Pinto LG, Peres RS, Silva JR, Almeida SC, LouzadaJunior P, Cunha TM, Cunha FQ, Alves-Filho JC. CCR2 Expression in Neutrophils Plays a Critical Role in Their Migration Into the Joints in Rheumatoid Arthritis. Arthritis Rheumatol. 2015; 67:1751-59.

40. Yokoyama W, Kohsaka H, Kaneko K, Walters M, Takayasu A, Fukuda S, Miyabe C, Miyabe Y, Love PE, Nakamoto N, Kanai T, Watanabe-Imai K, Charvat TT, et al. Abrogation of $\mathrm{CC}$ chemokine receptor 9 ameliorates collagen-induced arthritis of mice. Arthritis Res Ther. 2014; 16:445.

41. Chen Z, Kim SJ, Essani AB, Volin MV, Vila OM, Swedler W, Arami S, Volkov S, Sardin LV, Sweiss N, Shahrara S. Characterising the expression and function of CCL28 and its corresponding receptor, CCR10, in RA pathogenesis. Ann Rheum Dis. 2015; 74:1898-1906.

42. Prinz I, Gregoire C, Mollenkopf H, Aguado E, Wang Y, Malissen M, Kaufmann SH, Malissen B. The type 1 cysteinyl leukotriene receptor triggers calcium influx and chemotaxis in mouse alpha beta- and gamma delta effector T cells. J Immunol. 2005; 175:713-719.

43. Bautz F, Denzlinger C, Kanz L, Mohle R. Chemotaxis and transendothelial migration of $\mathrm{CD} 34(+)$ hematopoietic progenitor cells induced by the inflammatory mediator leukotriene D4 are mediated by the 7-transmembrane receptor CysLT1. Blood. 2001; 97:3433-3440.

44. Honig SM, Fu S, Mao X, Yopp A, Gunn MD, Randolph GJ, Bromberg JS. FTY720 stimulates multidrug transporterand cysteinyl leukotriene-dependent $\mathrm{T}$ cell chemotaxis to lymph nodes. J Clin Invest. 2003; 111:627-637. 